9 Taylor W, Pelmear PL. Scleroderma and its relation to Raynaud's phenomenon of occupational origin. Ontario: Ministry of Labour, Occupational Health and Safety Division, Toronto, Canada, 1985. (Occupational Health in Ontario 1985;6: No 2.)

10 Pyykkö I. Health effects and evaluation of the hand-arm vibration. Proceedings of the 4th international symposium on hand-arm vibration. Finland: Institute of Occupational Health, Helsinki (in press).

11 International Organisation for Standardisation. Draft international standard: ISO/DIS/5349. Guidelines for the measurement and the assessment of human exposure to hand-transmitted vibration. Geneva: International Organisation for Standardisation, 1984.

12 British Standards Institution. Draft for development, DD 43-1975. Guide to the evaluation of exposure of the human hand-arm system to vibration. London: British Standards Institution, 1983. exposure of the human hand-arm system to vibration. London: British Standards Institution, 1983.
American Conference of Governmental Industrial Hygierists. Threshold limit values for chemical substances and physical agents in the work environment. Cincinnati, Ohio: ACGIH, 1984-5:111-6. substances and physical agents in the work environment. Cincinnati, Ohio: ACGIH, 1984-5:111-6.
Johansson RS, Landström U, Lundström R. Responses of mechanoreceptive afferent units in the 14 Johansson RS, Landström U, Lundström R. Responses of mechanoreceptive afferent units in the
glabrous skin of the human hand to sinusoidal skin displacements. Brain Res 1982;244:17-25. 5 Juul C, Nielsen SL. Locally induced digital vasospasm detected by delayed rewarming in Raynaud's phenomenon of occupational origin. Brf Ind Med 1981;38:87-90.

16 Welsh CL. Digital rewarming time in the assessment of vibration-induced white finger. Proceedings of the 4th international symposium on hand-arm vibration. Finland: Institute of Occupational Health, Helsinki (in press).

17 Welsh CL. The effect of vibration on digital blood flow. Br J Surg 1980;67:708-10.

18 Bursh JH. Vibration-induced white finger-reversible or not? A preliminary report. In: Brammer AJ, Taylor W, eds. Vibration effects on the hand and arm in industry. New York: Wiley, 1982: $193-7$

19 Futatsuka $M$, Ueno $T$, Sakurai $T$. Follow up study of vibration-induced white finger in chain saw operators. Br f Ind Med 1985;42:267-71.

20 Gemne G, Taylor $\mathrm{W}$, eds. Hand-arm vibration and the central autonomic nervous system. Special volume of the fournal of Low Frequency, Noise, and Vibration. London: Multi-Science, 1983.

21 Futatsuka M, Yasutake N, Sakurai T, Matsumoto T. Comparative study of vibration disease among operators of vibrating tools by factor analysis. Brf Ind Med 1985;42:260-6.

22 Olsen N, Fjeldborg P, Brøchner-Mortensen J. Sympathetic and local vasoconstrictor response to cold in vibration-induced white finger. BrF Ind Med 1985;42:272-5.

\section{Helping the sick doctor: a new service}

As a member of the Merrison Committee of Inquiry into the Regulation of the Medical Profession I was very struck by the evidence we received concerning sick doctors. There were many dismal stories about practitioners whose competence to practise had plainly been impaired by illness, often psychiatric, but who soldiered on to the distress of their families and to the alarm of their colleagues.

Recommendations that the General Medical Council should establish a health committee were accepted by the government and found expression in the Medical Act 1978. We hoped that by holding proceedings in camera and by adopting a constructive attitude sick, incompetent doctors would be controlled and brought to treatment at an early stage.

The health procedures of the General Medical Council have turned out, probably inevitably, to be more formal (though still private) than the Merrison report envisaged. Nevertheless, within these constraints the council has accomplished excellent work in reclaiming sick doctors.

In the NHS hospital service controls operate through professional panels (the old "three wise men" arrangements), and in general practice the local medical committees may recommend suspension to a family practitioner committee. Experience suggests, however, that these statutory NHS devices are poorly understood and patchy in their application.

Many factors operate to deter a sick doctor from receiving help. Those with alcoholism or in morbid depression may have a profound lack of insight. The sick doctor may feel awkward and embarrassed at the thought of approaching colleagues in his own locality. He might, however, be willing to accept aid from further afield, but may not be sure whom to contact or may lack the initiative. His local colleagues, while experiencing growing concern, may hesitate to take action which might be construed as meddlesome or disloyal and instead develop a kind of protective collusion with the doctor.
In many cases there may be a stage in the evolution of the disorder when the sick doctor might be receptive and amenable to an offer of professional help from outside his region. It could be argued that such a step cuts across and abrogates the role of the doctor's own general practitionerbut for reasons which have been touched on above he may be impotent.

In an attempt to fill this gap informal services have been set up in Britain - notably by the Association of Anaesthetists of Great Britain and also by the Association of Surgeons. More recently, after an initiative by the British Medical Association supported by the Royal Colleges and Faculties, the Joint Consultants' Committee, and other professional medical bodies, a National Counselling and Welfare Service for Sick Doctors has been opened for all branches of the profession. This is controlled by an autonomous national management committee, including representatives from the interested medical organisations. The scheme is non-coercive, informal, and confidential. Any doctor who is seriously concerned about the effects of illness on the fitness to practise of a colleague may telephone a central contact point (01580 3160). He will be asked merely for the specialty of the sick doctor and the area in which he or she works. The name and telephone number of a national adviser will be provided, who will be one of a panel of senior doctors (nominated by the colleges and the BMA) in the same branch of medicine as the "patient." The colleague may then telephone the national adviser, and only at this stage need disclose names. The adviser, having discussed the problem, may himself make an approach to the "patient" or may arrange for another specialist within the service to do so.

This stage of direct approach is clearly the crucial and most difficult part of the operation. Sensitive handling by the national adviser will be of the essence. Many sick and troubled doctors may, however, respond to this proffered lifeline with a huge sense of relief. Some may even wish to seek help from the service on their own initiative.

No permanent records incorporating names will be kept of these transactions. The "patient" is perfectly entitled to refuse the offer-in which case the original referring colleague is informed and the matter closed so far as the counselling service is concerned.

K RAWNSLEY

Chairman, Management Committee,

National Counselling and Welfare Service for Sick Doctors, 7 Marylebone Road,

London NW1

\section{National Counselling and Welfare Service for Sick Doctors}

A confidential independent service supported by the Royal Colleges, $\mathcal{F C C}, B M A$, and other professional bodies

Are you concerned about a colleague whose health is affecting his or her work and who seems reluctant to acknowledge this or to seek help? Advice is available from senior doctors in all branches of the profession on a strictly confidential and informal basis.

Telephone the national contact point (01 5803160 ) for the name of an appropriate adviser. 